\title{
Environmental Factors Affecting the Mineralization of Crop Residues
}

\author{
Aleksandra Grzyb, Agnieszka Wolna-Maruwka * and Alicja Niewiadomska \\ Department of General and Environmental Microbiology, Poznań University of Life Sciences, ul. Szydłowska 50, \\ 60-656 Poznań, Poland; aleksandra.grzyb@up.poznan.pl (A.G.); alicja.niewiadomska@up.poznan.pl (A.N.) \\ * Correspondence: amaruwka@up.poznan.pl; Tel.: +48-618466724
}

Received: 25 September 2020; Accepted: 10 December 2020; Published: 12 December 2020

\begin{abstract}
The aim of this article is to present the issues related to the significance of microorganisms in the mineralization of crop residues and the influence of environmental factors on the rate of this process. Crop residues play a very important role in agriculture because they can be used both as an environment-friendly waste management strategy and as a means of improving soil organic matter. The inclusion of crop residues in the soil requires appropriate management strategies that support crop production and protect the quality of surface water and groundwater. Crops need nutrients for high yields; however, they can only absorb ionic forms of elements. At this point, the microorganisms that convert organically bound nitrogen, phosphorus, and sulfur into soluble $\mathrm{NH}_{4}{ }^{+}, \mathrm{NO}_{3}{ }^{-}, \mathrm{H}_{2} \mathrm{PO}_{4}{ }^{-}$, $\mathrm{HPO}_{4}{ }^{2-}$, and $\mathrm{SO}_{4}{ }^{2-}$ ions are helpful. Mineralization is the transformation of organic compounds into inorganic ones, which is a biological process that depends on temperature, rainfall, soil properties, the chemical composition of crop residues, the structure and composition of microbial communities, and the $\mathrm{C}: \mathrm{N}$ ratio in soil after the application of plant matter. An adjustment of the values of these factors enables us to determine the rate and direction of the mineralization of crop residues in soil.
\end{abstract}

Keywords: mineralization; soil microorganisms; crop residues; soil fertility

\section{Introduction}

Crop residues are post-harvest remains of agricultural, horticultural, and fruit crops. They are a valuable source of organic matter as well as micro- and macroelements when applied to the soil. The use of plant materials as soil conditioners may be a good recycling strategy as it influences the carbon (C) and nitrogen $(\mathrm{N})$ cycles in soil-plant systems. According to Franzluebbers [1] and Lal [2], carbon and nitrogen are two of the most important elements affecting soil productivity.

The process of mineralization or immobilization in the soil contributes to the circulation of these nutrients, and it is mediated by soil fauna and saprophytic as well as pathogenic microorganisms, which during the decomposition of dead plant material follow a saprophytic mode of life. The amount of nutrients and the rate of their release from crop residues depends on their qualitative characteristics and biochemical composition [3,4]. According to Martens [5], understanding the plant biochemistry will provide evidence for subsequent soil decomposition rates and serve as a means for possibly predicting $C$ sequestration. The author showed a correlation between the biochemical composition of plant residues and the rate of their decomposition as well as soil aggregation and its humus composition. By analyzing the rate of decomposition of corn (Zea mays L.), soybean (Glycine max L.), alfalfa (Medicago sativa L.), oat (Avena sativa L.), clover (Trifoium pratense L.), and rapeseed (Brassica napus L.) residues, he found that with the addition of plant residues, the aggregate stability initiated by microbial decomposition of the carbohydrate and amino acid content of the residue is then strengthened by interaction with phenolic acids such as vanillin or vanillic acid released by microbial decomposition from the structural components of residues. Ajwa and Tabatabai [6] 
analyzed the decomposition of organic matter of various origins, including plant residues, and they found that organic $C$ fractions in alfalfa (Medicago sativa L.) and sorghum (Sorghum vulgare Pers.) residues are more easily degraded than in corn (Zea mays L.) and soybean (Glycine max L.) residues. Moreover, total organic $\mathrm{C}$ mineralization did not reflect the $\mathrm{C}: \mathrm{N}$ ratio of the crop residues used, but rather, the mineralization increased with the higher total $\mathrm{N}$ content of the residue. Composition is also influenced by the physicochemical properties of soil, such as the $\mathrm{pH}$, humidity, aeration, elemental content, and climatic conditions, such as temperature and rainfall [7-13]. It is particularly important to recycle basic plant elements, i.e., nitrogen, phosphorus and sulfur, which are contained in organic residues. According to McMurtrie et al. [14], it is possible to predict a plant's demand for nutrients from the biomass accumulation model because the uptake of nutrients is proportional to the plant's photosynthetic activity, especially during vegetative growth. According to Whalen [15], it is extremely important that the release of nutrients from organic residues is synchronized with a plant's demand throughout the growing season. It is possible to reduce the use of mineral fertilizers if organic residues provide enough nutrients during a plant's growth.

\section{Microbiological Mineralization of Crop Residues}

Mineralization is the biological transformation of organic compounds into simpler inorganic compounds. As in many other biological processes, they are reduction and oxidation reactions in which organisms release the energy stored in reduced organic compounds, transforming them into more oxidized forms, and then use the obtained energy for the growth and development of their own cells. It is a stoichiometric process by which organisms acquire elements such as carbon, nitrogen, and phosphorus proportionally to the demand imposed by the elementary components of their cells [16]. According to Rusnak [17], 75-80\% of crop residues are mineralized into nutrients available to plants, whereas the remaining 20-25\% undergo humification, which results in the formation of soil humus.

Crop residues are an important source of organic matter; they can be reapplied into the soil to recycle nutrients and improve its physical, chemical, and biological properties [18]. The global production of crop residues is estimated to be 3.8 billion tons per year, $74 \%$ of which come from cereals, while $10 \%$ come from sugar plants, $8 \%$ come from legumes, $5 \%$ come from tubers, and $3 \%$ come from oilseeds [2]. Moreover, all agroecosystems have non-harvested parts of crops-roots and aerial residues such as leaves, stems, and husks [15]. According to Singh and Rengel [19], after harvest, crop residues can be (1) left on the soil surface, (2) arranged and wrapped in swaths, (3) reapplied into the soil, and/or (4) burnt before cultivation or preparation of the substrate. According to Henriksen and Breland [20], a knowledge of the dynamics of crop residues decomposition is necessary to manage agroecosystems. Decaying crop residues are considered basic components in the nutrient cycle; they also play a role in the protection of organic substances and the immobilization of nutrients in the soil structure. The application of crop residues into the soil reduces the risk of erosion and improves water retention in the soil [21]. According to Kumar and Goh [18], it is difficult to predict how many of the nutrients will be available to crops at a specific time due to the complex processes regulating the breakdown of crop residues and the release aliment. In addition, the nature of crop residues and the way they are handled may significantly affect the amount of nutrients available to plants as well as the content and quality of organic matter in the soil [22]. Depending on the type of organic matter, its turnover and persistence in soil ranges from less than one year to one thousand years. According to Martens [5] and Sapek [23], fresh plant material (mulch, crop residues) and the cells of soil microorganisms are the first to be mineralized and transformed, whereas humus, which is stable, is the most difficult to mineralize.

Soil microbial communities are the most abundant and diverse organisms on Earth; their biomass amounts to $5 \%$ of the soil organic matter. Microorganisms are responsible for many important ecological processes occurring in the soil ecosystem. They play a key role in the decomposition and circulation of nutrients as well as the formation of humic compounds in soil [24-26]. The size and activity of the microbial communities in soil depends on the quality of organic matter, its quantity, and its distribution. It is correlated with the physicochemical properties of soil, climatic conditions, and crop 
management [27]. Many researchers have come to the conclusion that the rate of the decomposition of crop residues is affected by the composition and activity of the soil microbiome, especially proteobacteria and actinobacteria, as well as the composition of plant debris [28-30]. According to Strickland et al. [31], the percentage of proteobacteria, acidobacteria, actinobacteria, and fungi Ascomycota changes with the time of plant residue decomposition. During the process, a decrease in the number of bacteria has been observed, with a simultaneous increase in the number of fungi.

Recent research by Nevins et al. [32] determine the impact of cover crop species on soil microbial community composition. After 21 days of incubation, Bacillus sp. and Rhodoplanes sp. were the most numerous group in vetch (Vicia villosa Roth) decomposition, while Rubrobacter sp. was the most numerous group in cereal rye (Secale cereale L.). Further analysis after 39 days showed the majority of Agromyces sp. in cereal rye residues. Kerdraon et al. [33] characterized an entire bacterial and fungal community in samples of wheat (Triticum aestivum L.) and oilseed rape (Brassica napus L.) residues. The impact of plant species on microbiota decreased over time with the replacement of oligotrophs, which are often plant-specific genera (such as pathogens) by copiotrophs, belonging to more generalist genera.

When harvest residues reach the soil, they are broken down by hydrolytic or oxidative processes into smaller particles with the participation of extracellular enzymes produced by microorganisms.

According to Kaleeem Abbasi et al. [3], this increases the surface of mineralized plant debris. As a consequence, it can be easily colonized by other types of microorganisms, and there is easier access to hydrolyzed polymer compounds (cellulose, lignin, protein). Plant residues are broken down by successive groups of microorganisms. Easily decomposable compounds are rapidly consumed by bacteria so that the recalcitrant fraction becomes proportionally greater, resulting in an increase in the fungal community. In the initial phase, bacteria with proteolytic and cellulolytic enzymes dominate; in later stages, this ratio changes in favor of nitrifiers. In the case of a fungal community, simple, soluble components (sugars) are uptaken first; then, this step is followed by fungi that are specialized polymer degraders. In the last step of decomposition, the most resistant fraction is broken down by fungi [34,35].

During the decomposition of plant parts, monomeric compounds (sugars, amino acids) are released, which then diffuse into the soil environment and are uptaken by the cell membrane of microorganisms for further in vivo hydrolysis, with the release of energy and secondary metabolites. For example, due to the content of nitrogen and, in some cases, sulfur (C-N and C-S) in amino acids, they are transformed into $\mathrm{NH}_{4}{ }^{+}$and $\mathrm{SO}_{4}{ }^{2-}$ ions through the action of intracellular amino acid hydrolases. As precursors of protein synthesis and other metabolic pathways, these soluble ions can be immobilized in microbial cells or released into the soil environment if the requirements of microbial metabolism have already been met. The lysis of microbial cells also contributes to the release of $\mathrm{NH}_{4}{ }^{+}$ and $\mathrm{SO}_{4}{ }^{2-}$ ions into the soil solution due to sudden changes in the soil caused by floods, droughts, freezing and thawing, or attacks from predators (e.g., nematodes) [15].

As observed from a study by Henriksen and Breland [20], unlike fresh herbaceous material, such as clover residues, straw has a low content of easily absorbable sugars and proteins; however, it is rich in cellulose and hemicelluloses. As a consequence, its decomposition depends on the adequate colonization and growth of microorganisms producing extracellular cellulases and hemicellulases. The role of molds is particularly significant in this process. According to Galus-Barchan and Chmiel [36], the following microorganisms exhibit strong cellulolytic properties: fungi of the Trichoderma, Fusarium, and Mycogone genera as well as eubacteria of the Cellulomonas sp., Cellvibrio sp., and Cytophaga sp. genera. Moreover, Koeck et al. [37] mentioned that cellulolytic properties are also present in microrganisms such as Bacillus sp., Clostridium sp. (especially C. thermocellum), Curtobacterium sp., Streptomyces sp., Thermobifida sp., and Flavobacterium sp.

Hemicelluloses (xylans, xyloglucan, arabinoxylans, and glucomannans) end up in soil together with plant debris. The complexity of a hemicellulose composition usually requires the action of a broad set of enzymes such as endoxylanases, endomannanases, xylosidases, glucosidases, and galactosidases [38]. According to Pérez et al. [39], this polysaccharide can be decomposed by some 
fungal species of the Aspergillus, Mucor, Rhizopus, Botrytis, and Cladysporium genera. In addition, active xylanases at alkaline $\mathrm{pH}$ were also found in Bacillus sp. and Streptomyces viridosporus as well as in yeasts of the Trichosporon sp., Cryptococcus sp., and Aureobasidium sp. genera.

Another microbial group that participates in the mineralization of plant debris is microorganism-producing amylolytic enzymes, which are capable of degrading starch into dextrins, maltose, and glucose. They produce $\alpha$-amylase, which catalyzes at random the hydrolysis of $\alpha-1,4$-glycosidic bonds inside the starch molecule and produces branched and linear oligosaccharides (dextrin, maltose, maltotriose, glucose) of various chain lengths. Amylolytic microorganisms include aerobic bacteria Bacterium sp., Pseudomonas sp., Amylobacter sp., Bacillus sp., Strepotmyces sp., and anaerobic bacteria, such as Clostridium sp. [40].

Pectins are another group of compounds that end up in the soil together with plant debris. Pectinases are the enzymes that decompose plant debris, which include pectin depolymerization enzymes (polygalacturonase and pectin lyase), as well as de-esterification enzymes (pectinomeryl esterase). Pectin is decomposed into various products, mainly galacturonic acid, depending on the nature of the enzymes that break it down into smaller molecules. Pectins are mostly decomposed by Penicillum sp., Trichoderma reesei, and Fusarium oxysporum fungi as well as eubacteria, i.e., Bacillus sp., Pseudomonas sp., Flavobacterium sp., Propionibacterium sp., and actinobacteria of the Streptomyces genus [41]. According to Jayani, [42] fungi Aspergillus sp., Rhizpous sp., Aureobasidium pullulans, Rhizoctonia solani, and bacteria Erwinia sp. have pectinolitic properties.

Lignin is one of the most complex compounds that enters the soil together with plant debris. This aromatic compound is very hard to decompose due to its complex structure, high molecular weight, and insolubility. It can be decomposed only by microorganisms that have the correct enzymes, such as laccase and tyrosinase. These are soil bacteria of the Azotobacter, Xanthomonas, Pseudomonas, and Agrobacterium genera and fungi Aspergillus sp., Penicillium sp., Trichoderma sp., and Chaetomium sp. [39]. According to Galus-Barchan and Chmiel [36], lignin is mostly decomposed by ascomycetes (Xylaria sp., Hypoxylon sp., Libertella sp.) and basidiomycetes (Trametes versicolor, Phanerochaete chrysosporium).

Apart from carbon, nitrogen is one of the most important elements supporting life on Earth. It is used in agriculture as the main factor affecting yield and contributing to food production [21]. If the supply of nitrogen in soil is limited, the growth of plants' root systems and shoots is inhibited, and plants have low crude protein content. Excess nitrogen in soil does not favor the normal development of plants either; rather, it delays their maturity and leads to excessive vegetative growth at the expense of grain yield. Therefore, it is important to use nitrogen efficiently to meet the demand of crops while limiting its overuse [43]. In the article of Albornoz [44], it is mentioned that overfertilization with $\mathrm{N}$ adversely affects the yield parameters and produce quality of plants. High rates of $\mathrm{N}$ application reduce organoleptic attributes such as the color, flavor, or aroma and the concentration of vitamin C, phenolic compounds, and sugar content.

As microorganisms and their activity are essential for the release of nitrogen from decaying organic materials; various factors influencing this process need to be taken into consideration, including the type of mineralized matter and climatic conditions. According to Gastal and Lemaire [45] and El-Jaual and Cox [46], plants usually take up nitrogen slowly after germination, intensively during vegetative growth, and then more slowly as they mature. Therefore, it is necessary to provide an adequate amount of this element at each stage of the plant's development. If the content of nitrogen and carbon in the soil is not adequately balanced, microorganisms and plants may compete for nitrogen. One of the sources of nitrogen in the soil is plant debris, which contains nitrogen in proteins, amino acids, and nucleic acids [47].

The first stage of nitrogen mineralization is proteolysis, i.e., the breakdown of proteins into amino acids, which can be taken up by microorganisms and plants. However, most of them undergo further changes during ammonification $[48,49]$. Protease is the enzyme used by microorganisms to hydrolyze peptide bonds. This ability is common among bacteria (including Proteus sp., Bacillus sp., and Pseudomonas sp., Streptomyces sp.) and fungi (Rhizopus sp., Aspergillus sp.) [50]. Jisha et al. [51] 
lists other microorganisms with proteolytic activity including Microbacterium sp., Brevibacterium sp., Fusarium sp., Purpureocillium lilacinum, and Engyodontium album.

Ammonification is the process in which amino acids undergo deamination and are converted as ammonia $\left(\mathrm{NH}_{3}\right)$, which is released in the presence of deaminases secreted by microorganisms. Then, ammonia is converted into ammonium ions $\left(\mathrm{NH}_{4}{ }^{+}\right)$, which are made available to plants and can undergo further microbiological processes, such as nitrification (Figure 1). Due to the high diversity of groups of microorganisms classified as ammonifiers, which include aerobes and anaerobes, psychrophiles, mesophiles, and thermophils, as well as microorganisms adapted to developing in an acidic or alkaline environment, ammonification can take place in various environments [52-54]. According to Piotrowska and Kusewicz [50] and Deacon et al. [55], the ammonification process is controlled by most bacteria and fungi, such as Bacillus sp., Clostridium sp., Proteus sp., Pseudomonas sp., Serratia sp., Escherichia coli, Curtobacterium flaccumfaciens, Trichoderma sp., Mortierella sp., and Mucor sp.

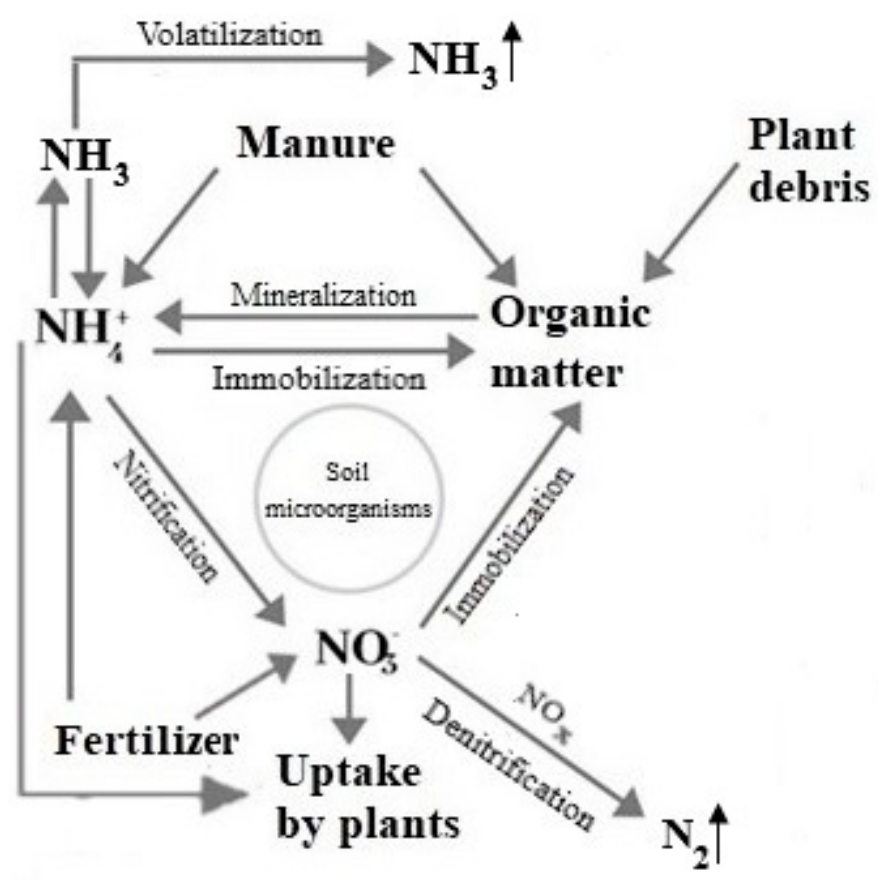

Figure 1. The course of mineralization of nitrogen compounds. Compiled by the author.

Apart from nitrogen, phosphorus is another nutrient that regulates plant growth and yield. This element is necessary for the course of energy reactions and cell division. Its total content in arable soils ranges from $0.02 \%$ to $0.5 \%$. There are millimolar amounts of most minerals in a soil solution, but phosphorus is available only in micromolar or smaller amounts. Soil microorganisms influence the availability of phosphorus for plants through the mineralization of organic matter (phospholipids, phosphoproteids, phytin) and the activation of water-insoluble phosphates [56]. Microorganisms, which are an integral part of the transformation of phosphorus compounds in soil, decompose plant debris added to soil and thus provide plants with phosphorus in the form of water-soluble phosphate ions $\left(\mathrm{PO}_{4}{ }^{3-}\right)$. Phosphatases of plant or microbiological origin (e.g., Aspergillus sp., Penicillum sp., Rhizopus sp., Bacillus sp., and Pseudomonas sp.) are enzymes that participate in the mineralization of organic phosphorus [57]. Kennelly [58] and Quiquampoix [59] add Yersinia sp., Aeromonas hydrophila, Escherichia coli, Campylobacter sp., Buchnera sp., and Lysobacter sp. to the previously mentioned examples. These enzymes can be divided into (1) phosphomonoesterases (phosphate mono-ester hydralases, EC 3.1.3.), (2) phosphodiesterases (phosphate diester hydralases, EC 3.1.4.) and (3) phosphotriesterases (phosphate triester hydralases, EC 3.1.5.) [60,61]. According to Eivazi and Tabatabai [62] and Bielińska [63], phosphomonoesterases can also be divided into alkaline (pH 8-10), neutral ( $\mathrm{pH}$ 6.5-7), and acidic ( $\mathrm{pH} 4-6)$, depending on the optimum $\mathrm{pH}$. 
Richardson and Simpson [64] noted that the increased activity of phosphatases in soil results from a deficit of phosphorus available to plants and is a part of the plant's response to phosphorus starvation. The degree of mineralization of phosphorus (P) from crop residues can usually be predicted from the total P content or the C:P ratio in the plant. However, the authors point to the limited accuracy of this forecasting procedure, because different forms of phosphorus contained in plant debris (phospholipids, RNA and phytate) are mineralized at different rates. According to Harasim [65], the content of phosphorus in the percentage of straw's dry weight amounts to 0.12 in cereal straw (wheat, rye, and barley), 0.14 in legumes (fava beans, peas, lupine) and 0.20 in maize stover. Estimated on the basis of the C:N ratio, Smernik and Baldock [66] observed that it is more difficult to predict the release of phosphorus from decomposed plant debris than the release of nitrogen. This is because crop residues contain a considerable amount of inorganic phosphorus, whereas the vast majority of nitrogen in crop residues is organic. Therefore, the release of nitrogen from mineralized plant debris is based only on microbial degradation, whereas phosphorus is partly released without microbial intervention.

Plant debris also contains sulfur (S), which is necessary to synthesize glucosinolates and produce sulfoxides and amino acids (cysteine and methionine). The recycling of crop residues in soil is an important source of sulfate ions $\mathrm{SO}_{4}{ }^{2-}$ for plants. According to Zhao et al. [67], currently, it is one of the most limiting nutrients in agricultural production in many European countries.

Similarly to the calculation of the C:N ratio in plant debris, in order to determine the amount of nitrogen available to plants, it is necessary to determine the availability of sulfur on the basis of the C:S ratio. Niknahad-Gharmakher [68] observed that amino acids containing sulfur, such as methionine and cysteine, were very quickly degraded by soil microorganisms. Therefore, sulfur is rapidly released from plant debris that is applied to the soil. These compounds account for about $90 \%$ of the total $S$ content in plants such as alfalfa. The rapid release of sulfur caused by sulfate solubilization and the hydrolysis of organic sulfates was described by Eriksen [69], who compared the rate of mineralization and immobilization of sulfur from 16 different plant residues, including wheat (Triticum aestivum L.), rye (Secale cereale L.), clover (Trifolium pretense L.), lupine (Lupinus luteus L.), and rapeseed (Brassica napus L.), in which the C:S ratio ranged from 50 to 600 , whereas the lignin content amounted to $0.9-10.8 \%$. The immobilization of sulfur in this study was strongly correlated with the value of the C:S ratio in the plant material, whereas there was a weaker, yet still significant, correlation with the lignin content.

The cycles of carbon and nitrogen as well as phosphorus and sulfur in the soil ecosystem are closely related to the decomposition of plant debris, which is transformed into mineral forms available to plants [16]. These forms can be $\mathrm{NOx}\left(\right.$ e.g., $\mathrm{N}_{2}$ and $\mathrm{N}_{2} \mathrm{O}$ ), which are released to the atmosphere, $\mathrm{H}_{2} \mathrm{~S}$, or nitrate $\left(\mathrm{NO}_{3}{ }^{-}\right)$, phosphate $\left(\mathrm{PO}_{4}{ }^{2-}\right)$, sulfate $\left(\mathrm{SO}_{3}{ }^{2-}\right)$, and ammonium $\left(\mathrm{NH}_{4}{ }^{+}\right)$ions, which plants can access easily.

The carbon-to-nitrogen ratio $(\mathrm{C}: \mathrm{N})$ is commonly used as an index to assess if the process of mineralization of plant debris will release or immobilize inorganic $N$ [70,71]. Crop residues contain about $40-50 \%$ of carbon in dry weight, but their nitrogen content varies significantly, which translates into differences in the C:N ratio. Usually, it is assumed that a C:N greater than 25:1 leads to the rapid immobilization of inorganic nitrogen. Thus, when wheat debris (C:N about 70-80:1) enters the soil, nitrogen is usually temporarily immobilized as a result of incorporation to microbial biomass. Legume debris, which has a lower $\mathrm{C}: \mathrm{N}$ ratio (about 25:1), will be mineralized and mineral nitrogen will be made available for plants. According to Dannehl et al. [72] and Hessen et al. [73], the C:N ratio of crop residues depends not only on the plant species but also on the type of cultivation, the length of the growing season, soil fertility, and environmental conditions. For example, the C:N ratio of young alfalfa hay is 15:1, whereas the ratio of mature alfalfa is 25:1 (Figure 2). 


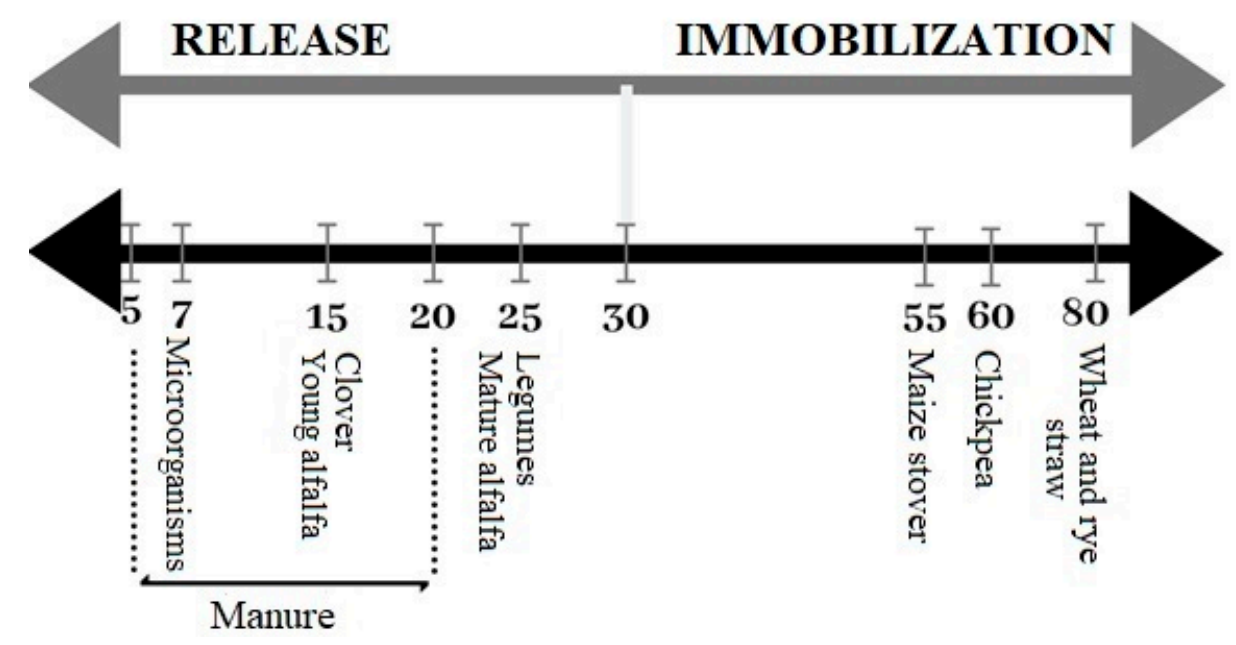

Figure 2. The carbon-to-nitrogen ratio $(\mathrm{C}: \mathrm{N})$ ratio of selected plants. Compiled by the Author.

Lynch et al. [74] studied the influence of the $\mathrm{C}: \mathrm{N}$ ratio on the rate of mineralization of plant debris and observed the highest degree of organic nitrogen decomposition in the debris with the lowest $\mathrm{C}: \mathrm{N}$ ratio. The researchers conducted a 112-day experiment in which they investigated the rate of organic nitrogen mineralization in the debris of maize (Zea mays L.), beans (Phaseolus vulgaris L.), hemp (Crotalaria juncea L.), and sorghum (Sorghum bicolor). The highest C:N ratio (56:1) was noted in maize, whereas the lowest ratio was noted in hemp (30:1). The researchers also found that $85 \%$ of nitrogen was mineralized in hemp residues, but only $54 \%$ was mineralized in common beans.

As results from the study conducted by Hadas et al. [71] show, plant materials have similar components but in different proportions. Each component is decomposed at a specific rate, and the proportions of these components are different. The researchers studied the decomposition of tobacco (Nicotiana tabacum L.), rapeseed (Brassica napus L.), maize (Zea mays L.), rice husk (Oryza sativa L.), and wheat (Triticum aestivum L.) residues in soil. Tobacco and rapeseed had a high content of nitrogen, and consequently, a low C:N ratio, whereas the nitrogen content in maize, rice husks, and wheat straw was low. Three groups of components were identified in all crop residues, which decomposed independently. The first group consisted of simple carbohydrates and amino acids, the second consisted of cellulosic compounds, and the third consisted of lignin. The researchers found that the mineralization of nitrogen contained in tobacco was 10\% greater than the mineralization of rapeseed. Carbon was equally divided between cellulose and lignin fractions in the rapeseed residues, whereas in tobacco residues, the greater part of carbon was included in lignin. According to the aforementioned authors, their study clearly showed that the rapid mineralization of nitrogen in tobacco residues, as opposed to the slow release of nitrogen from rapeseed, indicated the need to determine the distribution of $\mathrm{C}$ and $\mathrm{N}$ in various plant components rather than their total content in plant debris.

Plant materials consist of similar components, such as proteins, cellulose, hemicellulose, lignin, starch, lipids, and polyphenols, but they differ in their proportions, which determine the plant debris' rate of decomposition [71,75]. Additionally, crop residues include heterogeneous materials (roots, pods, leaves, and stalks) with different biochemical properties that affect the rate of their mineralization and the type of decomposition products [76,77].

Sariyildiz and Anderson [78] observed that the rate of decomposition of organic plant matter varies not only within the same species but also depends on the chemical composition and the stage of development of individual organs within one plant. Annoussamy et al. [79] found that the morphology and physical traits of plant tissues also play an important role in the decomposition of plant mass.

According to Magid et al. [80], dicotyledons differ from monocotyledons in the mechanism of decomposition of organic matter. Machinet et al. [77] studied the decomposition of maize residues and observed that the kinetics of carbon mineralization were also dependent on the genotype of the plant. 
Martens [5] analyzed the decomposition of crop residues and found that the C:N ratio in the plant material ranged from 10 to 103. Clover (Trifolium pratense) had the highest content of total organic carbon and total nitrogen ( $464 \mathrm{~g} \mathrm{~kg}^{-1} \mathrm{TOC}$ and $44.9 \mathrm{~g} \mathrm{~kg}^{-1} \mathrm{TN}$ ). Alfalfa (Medicago sativa) had the lowest content of organic carbon (350 $\mathrm{g} \mathrm{kg}^{-1} \mathrm{TOC}$ ), whereas maize (Zea mays L.) had the lowest content of total nitrogen $\left(4.3 \mathrm{~g} \mathrm{~kg}^{-1} \mathrm{TN}\right)$. The author also analyzed the content of phenolic acid and carbohydrates in these plants and found the lowest amounts in clover and the highest in maize. The research showed that plant debris with a higher content of carbohydrates was the first to be decomposed. The dynamics of these transformations were faster than in the plants containing phenolic compounds in their biomass.

Abiven et al. [81] assessed the influence of the chemical composition of various crop residues on the rate of their mineralization. They analyzed five crops: rice (Oryza sativa L.), soybean (Glycine max L.), sorghum (Sorghum spp.), brachiaria (Brachiaria ruziziesens Germ.), and wheat (Triticum aestivum L). The lignin fraction in the plants ranged from $3 \%$ (rice stalk and wheat leaves) to $26 \%$ (soybean roots) of the crop residue's dry weight. The carbon content ranged from $5.7 \%$ to $28.9 \%$, while that of polyphenols ranged from $0.32 \%$ (wheat roots) to $1.51 \%$ (rice leaves), and nitrogen content ranged from $0.4 \%$ (wheat stalks) to $4.4 \%$ (soybean leaves). The root debris of all the plants, except wheat, had a high content of the lignin fraction $(>15 \%)$, low content of soluble carbon and nitrogen, and a high concentration of polyphenols $(>1.1 \%)$. The organic matter mineralization of the crop roots was slower than that of the leaves and stems. The authors ascribed this phenomenon to the high content of lignin in these organs.

Prieto et al. [82] and Zhang and Wang [83] also concluded that the decomposition of organic matter of the crop roots and herbs is regulated by the chemical differences between their roots, such as the content of lignin, polysaccharides, polyphenols, and soluble fractions, as well as the C:N ratio. According to Silver and Miya [84], the chemical composition of roots seems to be the main factor affecting their decomposition, whereas climatic and environmental factors are of secondary importance.

Johnson et al. [85] analyzed the degree of mineralization of individual organs of alfalfa (Medicago sativa L.), maize (Zea mays L.), cuphea (Cuphea viscosissima Jacq.), soybean (Glycine max L.), and millet (Panicum virgatum L.) and arrived at similar conclusions about the influence of lignin content on the crop residue's rate of mineralization. The C:N ratio in these plants ranged from 10 (alfalfa leaves) to 110 (millet stalk). The total concentration of lignin ranged from $65 \mathrm{~g} \mathrm{~kg}^{-1}$ (alfalfa leaves) to $212 \mathrm{~g} \mathrm{~kg}^{-1}$ (soybean roots). The lignin-to-nitrogen ratio ranged from $1.5 \mathrm{~g} \mathrm{~kg}^{-1}$ (alfalfa leaves) to $40 \mathrm{~g} \mathrm{~kg}^{-1}$ (soybean stalks). The authors concluded that alfalfa leaves were mineralized at the fastest rate-they lost $50 \%$ of their carbon content during the 498 -day incubation period. Moreover, alfalfa roots were decomposed at a significantly higher rate than the other plants tested in the study.

Field experiments on the rate of decomposition of crop residues of winter rapeseed (Brassica napus ssp. Oleifera biennis), spring rapeseed (Brassica napus L.), winter wheat (Triticum aestivum L.), and red clover (Trifolium pretense L.), depending on their chemical composition, showed that red clover debris was characterized by the highest degree of lignin decomposition. The degree of decomposition of red clover stems was $42 \%$, whereas the degree of decomposition of red clover roots amounted to $34 \%$. The lowest rate of lignin mineralization, i.e., $17 \%$, was observed in winter rapeseed roots and wheat stalks [86]. The authors also found that unlike winter wheat residues, red clover debris was characterized by high nitrogen concentration and a low C:N ratio. Furthermore, the concentration of lignin in all the crop residues decreased significantly after 26 months of the experiment.

\section{The Influence of Environmental Factors on the Rate of Mineralization of Crop Residues}

During the decomposition of organic matter, microbial activity is controlled by physical, chemical, and biological factors, such as soil type, oxygenation, moisture, $\mathrm{pH}$, salinity, the content of organic matter and trace elements, the presence of stimulating or inhibiting substances, and the presence of other microorganisms. The course of the decomposition of organic matter is also significantly influenced by the climatic conditions, seasons of the year, agrotechnical treatments, the type of fertilization, as well as the plant cover, type, species, and even the variety and stage of development of the plant [87-89]. 
According to the results presented in a study by Pangnakorn et al. [90], Gough and Seiler [9], Wallenstein et al. [10], and Conant et al. [13] temperature is a key factor controlling the rate of decomposition of plant debris. In tropical climates, the rate of mineralization of plant-based organic matter is usually faster than in temperate climates. The rate of this process doubles whenever the mean annual air temperature increases by $8-9{ }^{\circ} \mathrm{C}$. Due to the faster rate of decomposition of plant debris in tropical climates, it is difficult to achieve a balance in organic matter content in soil agroecosystems. Therefore, in this climate zone, it is necessary to apply large amounts of organic matter to maintain its adequate amount in the soil. Soils in colder climates usually contain more organic matter because they are mineralized more slowly [90]. This hypothesis was confirmed in a study conducted by $\mathrm{Hu}$ et al. [91], who investigated the influence of six temperature ranges $\left(-10,5,15,25,35\right.$, and $\left.40^{\circ} \mathrm{C}\right)$ and four rainfalls $(5,10,15$, and $30 \mathrm{~mm})$ on the rate of mineralization of plant debris in the soil. The authors observed that temperatures of 25,35 , and $40{ }^{\circ} \mathrm{C}$ as well as moderate rainfall (10 and $15 \mathrm{~mm}$ ) accelerated nitrogen mineralization in the soil. Chow et al. [92] also found that a higher soil temperature increased the activity of microorganisms and the rate of mineralization of plant organic matter. The authors incubated peat soil for 60 days at various temperatures, i.e., 10,20 , and $30^{\circ} \mathrm{C}$ and observed that the average indexes of organic carbon mineralization amounted respectively to 11.2, 25.7, and $42.1 \mu \mathrm{g}-\mathrm{C} \mathrm{g}^{-1}$.

Hassan et al. [12], studied the distribution of rice straw and green manure in soil at various temperature ranges (from 5 to $45^{\circ} \mathrm{C}$ ), and they showed that the rate of mineralization of plant residues increased with increasing temperature. However, according to researchers, temperature is an important, but indirect, regulator of microbial degradation of crop residues. The research confirmed a significant impact of soil moisture on the production and emission of $\mathrm{CO}_{2}$ in the soil during the decomposition of plant residues. In addition, Hood [8] analyzed the distribution of soybean residues in soil, showing that the percentage of nitrogen released from plant residues increased linearly with increasing soil temperature and humidity.

Soil moisture is another factor influencing the decomposition of crop residues. The presence or lack of water significantly influences the activity of soil microorganisms and consequently, the rate of mineralization and immobilization of organic nitrogen. There are several interrelated mechanisms that reduce the activity of soil microorganisms depending on the content of water. In dry soil, these are a reduced diffusion of soluble compounds, a reduced mobility of microorganisms and, consequently, a limited access of microorganisms to the substrate. The activity of aerobic microorganisms may also be limited in very wet soil due to the hindered diffusion of oxygen. According to Paul [93], the activity of microorganisms in dried soils is lower because their population decreases due to limited access to organic materials and nutrients, which dissolve in water retained in soil pores. On the other hand, in flooded soils, the microbial population has no access to oxygen because water fills soil pores, which are naturally filled with air. According to a study conducted by Paul et al. [94], the relation between the soil water content and microbial activity is extremely complex, because it is determined by the soil type and porosity, organic matter concentration, $\mathrm{pH}$, and soil depth.

Devevre and Horwath [95] conducted a 160-day experiment in which they studied the decomposition of rice straw in soil under aerobic and anaerobic conditions (soil flooded with water) at three temperatures $\left(5,15\right.$, and $\left.25^{\circ} \mathrm{C}\right)$. They observed a slower rate of carbon mineralization and increased production of methane $\left(\mathrm{CH}_{4}\right)$ in the soils flooded with water. The mineralization of rice straw in the non-flooded soil at $25^{\circ} \mathrm{C}$ was $55 \%$, whereas at $5{ }^{\circ} \mathrm{C}$, it was only $27 \%$. The course of the mineralization process in the flooded soil was different. The mineralization of straw at $25^{\circ} \mathrm{C}$ was $47 \%$, whereas at $5{ }^{\circ} \mathrm{C}$, the decomposition amounted to $19 \%$.

Kruse et al. [96] also studied the influence of the soil water content on the rate of decomposition of plant debris. The researchers conducted a 185-day experiment, in which they analyzed the decomposition of upland cotton leaves (Gossypium hirsutum L.) in constantly moist soil. They observed $30 \%$ mineralization of nitrogen; however, when the leaves were decomposed over the same period 
of time, but with thirteen drought cycles lasting 14 days each, nitrogen was immobilized in the soil microorganisms' cells.

Fierer and Schimel [97] found that the average respiration rates in the soil exposed to 15 dry and rewetting cycles were significantly lower than in the soil that was not exposed to this stress. According to researchers, drought may cause an increase in the content of inorganic nitrogen in soil as a result of the death of microbial cells and their mineralization, which then release inorganic nitrogen.

The research findings clearly showed that soil moisture affects the rate of mineralization of organic matter. It may also be influenced by crop residues, which retain water in the soil. This was confirmed by the results obtained in a study conducted by Klocke et al. [98], who studied the degree of water evaporation from the soil under a maize plantation into which wheat or maize residues had or had not been added. The researchers observed that the application of crop residues to the soil surface reduced evaporation by $20 \%$. This clearly indicates the possibility of economical water management, resulting from the proper management of crop residues.

The type of soil is another factor that influences the rate of mineralization of organic matter. There are many minor factors that contribute to the type of soil, such as components of the solid fractions in soil (sand, clay, etc.), organic matter content, particle size distribution, $\mathrm{pH}$, and cation exchange capacity, all of which affect the evolution of organic compounds in soil [99]. This hypothesis was confirmed in a study by Khalil et al. [4], who investigated the decomposition of wheat residues (Triticum aestivum L.) in soil samples with different sand and clay content, which was collected from a depth of 0-15 cm during a 90-day incubation period. The researchers found that the process of nitrogen mineralization in soils with high sand content and low clay content may reach a high level. After mineralization in wheat, the soils differed considerably in their content of nitrogen, which amounted to $70.64 \mathrm{mg} \mathrm{N} \mathrm{kg}^{-1}$ of soil with higher sand content and $53.15 \mathrm{mg} \mathrm{N} \mathrm{kg}^{-1}$ of soil with higher clay content.

Moreover, a study conducted by Froseth and Bleken [100], who incorporated clover leaves into silty clay loam (clay soil) and a sandy loam (sandy soil) for 142 days, found $20 \%$ higher mineralization in the sandy soil than in the clay soil. The explanation of this result could lie in the reduced diffusion of enzymes and other solutes related to the specific properties of the clay soil, because it is known that clay content decreases diffusion, which depends exponentially on the pore-size distribution index. Schmatz et al. [101] achieved the same results after the incorporation of wheat, pea, and vetch residues into sandy-loam and clay soils. They conducted the incubations for 360 days, and the mineralization of all three crop resides was higher in sandy-loam soil.

The concentration of heavy metals in soil, its salinity, and $\mathrm{pH}$ may significantly affect the mineralization of plant debris. Studies by Ekenler and Tabatabai [102] showed that when metals such as $\mathrm{Ag}, \mathrm{Hg}$, and $\mathrm{Cu}$ were added, they inhibited the activity of $\beta$-glucosamidase - the enzyme associated with nitrogen mineralization in soil.

One of the fundamental factors influencing the microbial environment in soil is the $\mathrm{pH}$ value. According to Kemmitt et al. [103] and Pietri and Brookes [104], it strongly affects abiotic factors, such as the availability of nutrients, the rate of carbon and nitrogen cycles in the environment, and the solubility of metals, as well as biotic factors, such as the composition and activity of the fungal and bacterial communities in agricultural soils.

Results from a study conducted by Mandal et al. [105] showed that crop residues applied into the soil affect the proliferation and activity of soil microorganisms by changing the soil $\mathrm{pH}$ due to the decarboxylation of organic anions from mineralized organic matter. According to Kumar and Goh [106], the decomposition of crop residues in neutral soils is more intense than in acidic soils. The research showed that during the mineralization of organic matter, the soil $\mathrm{pH}$ significantly influenced the type of nitrogen forms generated. Through the $\mathrm{N}$ cycle, the ammonification of organic $\mathrm{N}$ and nitrate uptake increased $\mathrm{pH}$, whereas nitrification and ammonium uptake decreased $\mathrm{pH}$. Bergman et al. [107] analyzed the degree of mineralization of selected carbohydrates (glucose and starch) in acidic peat at various $\mathrm{pH}$ values $(4.3 ; 6.2 ; 6.8)$, and they observed that both the aerobic and anaerobic degradation of glucose was limited by low $\mathrm{pH}$ values of the peat $(\mathrm{pH}=4.3)$. 
Zhao et al. [108] limed acidic subtropical forest soil ( $\mathrm{pH}$ 4.6) and increased its $\mathrm{pH}$ to 8.1. They analyzed the rate of organic nitrogen mineralization during a 40-day incubation period at $25^{\circ} \mathrm{C}$. They observed that as the soil $\mathrm{pH}$ increased, the rate of soil organic matter mineralization grew from 3.39 to $8.54 \mathrm{mg} \mathrm{N} \mathrm{kg}^{-1}$ day $^{-1}$.

Butterly et al. [11], analyzed the content of available nitrogen forms in various types of soil during the mineralization of canola (Brassica napus), chickpea (Cicer arietinum L.), and wheat (Triticum aestivum L.) residues and showed that the nitrogen content depended on both the type of plant debris as well as soil. Nevertheless, in all experimental variants, an increase in soil $\mathrm{pH}$ was noted in the third month of the study, with a simultaneous increase in the content of ammonium ions (especially after the use of canola and chickpea residues).

Kemmitt et al. [103] investigated the influence of the $\mathrm{pH}$ value on the rate of ammonification and nitrification process in soil enriched with amino acids, and they showed that acidification during arginine decomposition did not affect the ammonification rate, but it decreased the rate of nitrification. In addition, the research by $\mathrm{Hu}$ et al. [109] confirmed the reduction of the activity of nitrification microorganisms in soil during its acidification. However, according to Booth et al. [110], active nitrification activity was found in a wide variety of acid soils, even at $\mathrm{pH}$ values as low as 3 .

According to the review of reference publications, the method of applying crop residues into soil also affects the dynamics of their decomposition, both in the field and in the laboratory. Henriksen and Breland [20] showed that the rate of decomposition of barley straw applied to the soil surface was lower than in deeper layers of the substrate. This phenomenon was caused by a greater contact of plant residues with the soil, which was a better and more stable microenvironment with a higher supply of nutrients for the microorganisms decomposing crop residues. Bailey and Lazarovits [111] conducted a study on Australian soils and found that under semi-arid environmental conditions, the decomposition of wheat straw was greater when it was partially applied or buried in the soil rather than left on its surface. The researchers observed that the half-life of buried wheat straw residues was 7-9 months, whereas the half-life of those left on the soil surface was 24 months.

\section{The Benefits of Using Crop Residues in Agricultural Production}

Plant debris affects the soil structure, texture, and population of soil organisms. It is a source of nutrients for soil microorganisms, protects soil from the erosive influence of water and wind, as well as improving its hydrological properties, water infiltration, and runoff. It increases soil porosity, water retention, gas streams, heat streams, and the availability of macro- and microelements in soil [112].

A study conducted by Pandiaraj et al. [113] showed that crop residues applied into soil improved its fertility, increased the cultivation efficiency, and prevented the loss of nutrients, which otherwise might have been washed out of the substrate. The researchers observed that the application of crop residues increased the content of mineral nitrogen in the soil by 1.22 times, the amount of nitrogen in wheat grain by 1.32 times, and in the wheat straw by 1.67 times, as compared with the control variant, where no crop residues were applied. The research also showed that the addition of crop residues to the soil increased the yield of wheat grain by 1.22 times in the first year of the experiment and 1.38 times in the second year. Kumar and Goh [106] and Surekha et al. [114] noted a significant increase in the content of mineral nitrogen in the soil after the treatment with wheat and rice residues. Schafi et al. [115] analyzed the influence of wheat (Triticum aestivum L.) and lentil (Lens culinaris Medik.) residues on the yield of maize (Zea mays L.) and observed better effects after the treatment with lentil residues. When the residues were applied as mulch, the grain yield increased by $3.31 \%$, whereas when they were applied into deeper soil layers, the yield increased by $6.72 \%$. The yield of maize stover increased respectively by $5.39 \%$ and $10.27 \%$ in relation to the control variant (the soil without additives), depending on the method of application of lentil residues.

In agricultural practice, the management of crop residues also reduces the incidence of soil-borne plant diseases. The presence of crop residues in soil may directly influence the viability and activity of plant pathogens in the substrate. Arnault et al. [116] combined laboratory and field experiments 
to investigate the practical potential of onion residues (Allium cepa L.) compounds. The researcher concluded that onion residues have a significant effect on soil-borne pathogens because of the higher concentration of disulfides diffused through the soil. In addition to onion, garlic residues (Allium sativum L.) also exhibit multiple bioactive properties such as inhibitory effects on a variety of soil microorganisms, due to the production of numerous sulfur-containing chemical products that can act upon fungi and bacteria. Summarizing, the properties of Allium residues are tightly linked to the complex biochemistry of the sulfur compounds they contain (cysteine, cystine, methionine, glutathione), which degrade with the beneficial effects in controlling Fusarium oxysporum and Verticillium dahlia $[117,118]$.

Unfortunately, crop residues may also increase the risk of "residue-borne" diseases, acting as a source of primary inoculum. Several leaf- and stem-infecting microorganisms (potential plant pathogens) survive on crop residues and proliferate as saprophytes on them [119]. This was confirmed by the research of Suffert and Sache [120], where plant remains with identified Pyrenophora tritici-repentis causing a tan spot in wheat were likely to infect subsequent growing wheat (Triticum aestivum L.). Vera and Murray [121] obtained the same results, where Oculimacula yallundae and Oculimacula acuformis on cereal debris were the primary inoculum attacking wheat crops (Triticum aestivum L.).

Apart from limiting the development of pathogens, some crop residues inhibit (allelopathic effect) the growth of weeds by reducing their access to light, changing soil temperature, and producing chemical substances [122]. This hypothesis was confirmed by a study conducted by Chauhan et al. [123], who investigated the influence of rye (Secale cereale) and wheat (Triticum aestivum L.) residues on the development of weeds. Rye is commonly used as a ground cover crop that reduces the density and biomass of several weed species in soybean and maize plantations. The research clearly showed that rye residues reduced the biomass and density of weeds such as lamb's quarters (Chenopodium album L.), hairy crabgrass (Digitaria sanguinalis L.), and common purslane (Portulaca oleracea L.) in a maize plantation by more than $75 \%$ in comparison with the plantation where no crop residues had been used. However, the researchers also noted that the residues of some crops, e.g., wheat, may stimulate the germination of weed seeds such as common wild oats (Avena fatua L.).

\section{Summary}

This review of publications on the microbiological mineralization of crop residues showed that they significantly protect the soil organic matter and return nutrients to the substrate. The use of local organic plant-based materials in agricultural practice is gaining worldwide support because they improve the fertility and production potential of degraded soils with a low content of nutrients. Moreover, it is an alternative method to conventional fertilization and a sustainable way of enriching soils with nutrients for plants without disturbing their biological balance.

There are numerous environmental factors influencing the rate of microbiological mineralization of crop residues in soil and the provision of nutrients to plants. These include the chemical composition of plant residues, temperature, the content of water in the soil, its granulometric composition, and the presence of a specific microbiome. The effective management of crop residues should be based on the correct balance of plant nutrients. It should protect the soil and its resources to ensure optimal crop yield. When managing crop residues while growing crops, it is necessary to consider the following: (1) whether the decomposition and mineralization of plant organic matter by soil microorganisms can provide sufficient amounts of nitrogen and phosphorus at critical stages of a plant's growth; (2) the plants' nutritional requirements at various critical stages of their growth; and (3) what amount of the elements released during the degradation and mineralization processes is assimilated by crops at various critical stages of their growth. Answering these questions will enable an effective management of crop residues, which is in line with the current agricultural policy of integrated pest management (Directive 2009/128/EC and Regulation 1107/2009/EC) [124,125] adopted by the EU member-states, including Poland. 
Author Contributions: Writing—original draft preparation, A.G.; writing—review and editing, A.W.-M., A.N. All authors have read and agreed to the published version of the manuscript.

Funding: This research received no external funding.

Conflicts of Interest: The authors declare no conflict of interest.

\section{References}

1. Franzluebbers, A.J. Ecology: Cycling of carbon and nitrogen. In Encyclopedia of Soil Science; Lal, R., Ed.; CRC Press: Boca Raton, FL, USA, 2017; pp. 711-715.

2. Lal, R. World crop residues production and implications of its use as a biofuel. Environ. Int. 2005, 31, 575-584. [CrossRef] [PubMed]

3. Abbasi, M.K.; Tahir, M.M.; Sabir, N.; Khurshid, M. Impact of the addition of different plant residues on nitrogen mineralization-immobilization turnover and carbon content of a soil incubated under laboratory conditions. Solid Earth 2015, 6, 197-205. [CrossRef]

4. Khalil, M.I.; Hossain, M.B.; Schmidhalter, U. Carbon and nitrogen mineralization in different upland soils of the subtropics treated with organic materials. Soil Biol. Biochem. 2005, 37, 1507-1518. [CrossRef]

5. Martens, D. Plant residue biochemistry regulates soil carbon cycling and carbon sequestration. Soil Biol. Biochem. 2000, 32, 361-369. [CrossRef]

6. Ajwa, H.A.; Tabatabai, M.A. Decomposition of different organic materials in soils. Biol. Fertil. Soils 1994, 18, 175-182. [CrossRef]

7. Clayden, J.; Greeves, N.; Warren, S.; Wathers, P. Chemia Organiczna Cz. IV; WNT: Warszawa, Polska, 2016; p. 384 .

8. Hood, R.C. The Effect of soil temperature and moisture on organic matter decomposition and plant growth. Isotopes Environ. Health Stud. 2001, 37, 25-41. [CrossRef]

9. Gough, C.M.; Seiler, J.R. The influence of environmental, soil carbon, root, and stand characteristics on soil $\mathrm{CO}_{2}$ efflux in loblolly pine (Pinus taeda L.) plantations located on the South Carolina Coastal Plain. For. Ecol. Manag. 2004, 191, 353-363. [CrossRef]

10. Wallenstein, M.; Allison, S.D.; Ernakovich, J.; Steinweg, J.M.; Sinsabaugh, R. Controls on the temperature sensitivity of soil enzymes: A Key Driver of In Situ Enzyme Activity Rates. In Soil Enzymology; Shukla, G., Varma, A., Eds.; Springer: Berlin/Heidelberg, Germany, 2010; Volume 22, pp. 245-258.

11. Butterly, C.R.; Baldock, J.A.; Tang, C. The contribution of crop residues to changes in soil $\mathrm{pH}$ under field conditions. Plant Soil 2013, 366, 185-198. [CrossRef]

12. Hassan, W.; David, J.; Abbas, F. Effect of type and quality of two contrasting plant residues on $\mathrm{CO}_{2}$ emission potential of Ultisol soil: Implications for indirect influence of temperature and moisture. Cantena 2014, 114, 90-96. [CrossRef]

13. Conant, R.T.; Ryan, M.G.; Ågren, G.I.; Birge, H.E.; Davidson, E.A.; Eliasson, P.E.; Evans, S.E.; Frey, S.D.; Giardina, C.P.; Hopkins, F.M.; et al. Temperature and soil organic matter decomposition rates-synthesis of current knowledge and a way forward. Glob. Chang. Biol. 2011, 17, 3392-3404. [CrossRef]

14. McMurtrie, R.E.; Iversen, C.M.; Dewar, R.C.; Medlyn, B.E.; Näsholm, T.; Pepper, D.A.; Norby, R.J. Plant root distributions and nitrogen uptake predicted by a hypothesis of optimal root foraging: Optimal Root Foraging. Ecol. Evol. 2012, 2, 1235-1250. [CrossRef] [PubMed]

15. Whalen, J.K. Managing Soil biota-mediated decomposition and nutrient mineralization in sustainable agroecosystems. Adv. Agric. 2014, 1-13. [CrossRef]

16. Bridgham, S.D.; Ye, R. Organic matter mineralization and decomposition. In SSSA Book Series; DeLaune, R.D., Reddy, K.R., Richardson, C.J., Megonigal, J.P., Eds.; American Society of Agronomy and Soil Science Society of America: Madison, WI, USA, 2015; pp. 385-406.

17. Rusnak, J. How to Improve Soil Fertility? Agricultural Advisory Center: Karniowice, Poland, 2017.

18. Kumar, K.; Goh, K.M. Crop residues and management practices: Effects on soil quality, Soil nitrogen dynamics, crop yield, and nitrogen recovery. Adv. Agron. 1999, 68, 197-319.

19. Singh, B.; Rengel, Z. The role of crop residues in improving soil fertility. In Nutrient Cycling in Terrestrial Ecosystems; Marschner, P., Rengel, Z., Eds.; Soil Biology; Springer: Berlin/Heidelberg, Germany, 2007; Volume 10, pp. 183-214. 
20. Henriksen, T.; Breland, T. Carbon mineralization, fungal and bacterial growth, and enzyme activities as affected by contact between crop residues and soil. Biol. Fertil. Soils 2002, 35, 41-48. [CrossRef]

21. Chen, B.; Liu, E.; Tian, Q.; Yan, C.; Zhang, Y. Soil nitrogen dynamics and crop residues. A review. Agron. Sustain. Dev. 2014, 34, 429-442. [CrossRef]

22. Yadvinder-Singh, B.S.; Timsina, J. Research Publications Repository-Crop residue management for nutrient cycling and improving soil productivity in rice-based cropping systems in the tropics. Adv. Agron. 2005, 85, 269-407.

23. Sapek, B. Nitrogen and phosphorus release from soil organic matter. Water Environ. Rural Areas 2010, 10, 229-256.

24. Bardgett, R.D.; van der Putten, W.H. Belowground biodiversity and ecosystem functioning. Nature 2014, 515, 505-511. [CrossRef]

25. Rashid, M.I.; Mujawar, L.H.; Shahzad, T.; Almeelbi, T.; Ismail, I.M.I.; Oves, M. Bacteria and fungi can contribute to nutrients bioavailability and aggregate formation in degraded soils. Microbiol. Res. 2016, 183, 26-41. [CrossRef]

26. Jamir, E.; Kangabam, R.D.; Borah, K.; Tamuly, A.; Deka Boruah, H.P.; Silla, Y. Role of Soil microbiome and enzyme activities in plant growth nutrition and ecological restoration of soil health. In Microbes and Enzymes in Soil Health and Bioremediation; Kumar, A., Sharma, S., Eds.; Microorganisms for Sustainability; Springer: Singapore, 2019; pp. 99-132.

27. Nieder, R.; Benbi, D.K. Carbon and nitrogen transformations in soils. In Carbon and Nitrogen in the Terrestrial Environment; Nieder, R., Benbi, D.K., Eds.; Springer Science \& Business Media: Dordrecht, The Netherlands, 2008; pp. 137-159.

28. Waring, B.G.; Averill, C.; Hawkes, C.V. Differences in fungal and bacterial physiology alter soil carbon and nitrogen cycling: Insights from meta-analysis and theoretical models. Ecol. Lett. 2013, 16, 887-894. [CrossRef]

29. Arcand, M.M.; Helgason, B.L.; Lemke, R.L. Microbial crop residue decomposition dynamics in organic and conventionally managed soils. Appl. Soil Ecol. 2016, 107, 347-359. [CrossRef]

30. Gupta, V.V. Biological factors influence $\mathrm{N}$ mineralization from soil organic matter and crop residues in Australian cropping systems. Red 2016, 500, 35-55.

31. Strickland, M.S.; Lauber, C.; Fierer, N.; Bradford, M.A. Testing the functional significance of microbial community composition. Ecology 2009, 90, 441-451. [CrossRef] [PubMed]

32. Nevins, C.J.; Nakatsu, C.; Armstrong, S. Characterization of microbial community response to cover crop residue decomposition. Soil Biol. Biochem. 2018, 127, 39-49. [CrossRef]

33. Kerdraon, L.; Balesdent, M.-H.; Barret, M.; Laval, V.; Suffert, F. Crop residues in wheat-oilseed rape rotation system: A Pivotal, Shifting Platform for Microbial Meetings. Microb. Ecol. 2019, 77, 931-945. [CrossRef] [PubMed]

34. Ruess, L.; Ferris, H. Decomposition pathways and successional changes. Nematol. Monogr. Perspect. 2004, 2, 547-556.

35. Bastian, F.; Bouziri, L.; Nicolardot, B.; Ranjard, L. Impact of wheat straw decomposition on successional patterns of soil microbial community structure. Soil Biol. Biochem. 2009, 41, 262-275. [CrossRef]

36. Galus-Barchan, A.; Chmiel, M.J. The role of microorganisms in acqisition of nutrients by plants. Kosmos 2019, 68, 107-114. [CrossRef]

37. Koeck, D.E.; Pechtl, A.; Zverlov, V.V.; Schwarz, W.H. Genomics of cellulolytic bacteria. Curr. Opin. Biotechnol. 2014, 29, 171-183. [CrossRef]

38. López-Mondéjar, R.; Zühlke, D.; Becher, D.; Riedel, K.; Baldrian, P. Cellulose and hemicellulose decomposition by forest soil bacteria proceeds by the action of structurally variable enzymatic systems. Sci. Rep. 2016, 6, 25279. [CrossRef]

39. Pérez, J.; Muñoz-Dorado, J.; de la Rubia, T.; Martínez, J. Biodegradation and biological treatments of cellulose, hemicellulose and lignin: An overview. Int. Microbiol. 2002, 5, 53-63. [CrossRef] [PubMed]

40. Sharma, A.K.; Sharma, V.; Saxena, J.; Chandra, R.; Alam, A.; Prakash, A. Isolation and screening of amylolytic bacteria from soil. Int. J. Sci. Res. Agric. Sci. 2015, 2, 159-165. [CrossRef]

41. Breza-Boruta, B. Occurrence of pectinolytic microorganisms in soil cultivated under organic and conventional cropping systems. Pol. J. Agron. 2013, 15, 32-37.

42. Jayani, R.S.; Saxena, S.; Gupta, R. Microbial pectinolytic enzymes: A review. Process Biochem. 2005, 40, 2931-2944. [CrossRef] 
43. Johnson, C.; Albrecht, G. Nitrogen basics-the nitrogen cycle. Agron. Fact Sheet Ser. Fact Sheet 2005, 2, 1-2.

44. Albornoz, F. Crop responses to nitrogen overfertilization: A review. Sci. Hortic. 2016, 205, 79-83. [CrossRef]

45. Gastal, F.; Lemaire, G. N uptake and distribution in crops: An agronomical and ecophysiological perspective. J. Exp. Bot. 2002, 53, 789-799. [CrossRef]

46. El-Jaoual, T.; Cox, D. Effects of plant age on nitrogen uptake and distribution by greenhouse plants. J. Plant Nutr. 1998, 21, 1055-1066. [CrossRef]

47. Jones, D.L.; Healey, J.R.; Willett, V.B.; Farrar, J.F.; Hodge, A. Dissolved organic nitrogen uptake by plants-An important N uptake pathway? Soil Biol. Biochem. 2005, 37, 413-423. [CrossRef]

48. Wyczółkowski, A.; Dabek-Szreniawska, M. Enzymes taking part in organic nitrogen mineralization. Acta Agroph. 2005, 3, 37-61.

49. Nannipieri, P.; Kandeler, E.; Ruggiero, P. Enzyme activities and microbiological and biochemical processes in soil. In Enzymes in the Environment: Activity, Ecology, and Applications; Burns, R.G., Dick, R.P., Eds.; Marcel Dekker: New York, NY, USA, 2002; pp. 1-33.

50. Piotrowska, M.; Kusewicz, D. Soil microflora. In Technical Microbiology; Microorganisms and their environment; Libudzisz, Z., Kowal, K., Eds.; Scientific Publisher PWN: Warszawa, Poland, 2007; pp. 195-200.

51. Jisha, V.; Smitha, R.B.; Pradeep, S.; Sreedevi, S.; Unni, K.N.; Sajith, S.; Priji, P.; Sarath Josh, M.; Benjamin, S. Versatility of microbial proteases. Adv. Enzym. Res. 2013, 1, 39-51. [CrossRef]

52. Dabek-Szreniawska, M.; Zimon, A.; Wyczółkowski, A.I. Soil enzymes activity of amonification process in the soil with the addition of organic nitrogen. Acta Agroph. 2006, 8, 23-33.

53. Strock, J.S. Ammonification. In Encyclopedia of Ecology, Five-Volume Set; Joegensen, S.E., Fath, B.D., Eds.; Elsevier Science: Amsterdam, The Netherlands, 2008; pp. 162-165.

54. Romillac, N. Ammonification. In Encyclopedia of Ecology; Fath, B.D., Ed.; Elsevier: Amsterdam, The Netherlands, 2019; pp. 256-263.

55. Deacon, L.J.; Pryce-Miller, E.J.; Frankland, J.C.; Bainbridge, B.W.; Moore, P.D.; Robinson, C.H. Diversity and function of decomposer fungi from a grassland soil. Soil Biol. 2006, 38, 7-20. [CrossRef]

56. Deubel, A.; Merbach, W. Influence of Microorganisms on phosphorus bioavailability in soils. In Microorganisms in Soils: Roles in Genesis and Functions; Varma, A., Buscot, F., Eds.; Soil Biology; Springer: Berlin/Heidelberg, Germany, 2005; Volume 3, pp. 177-191.

57. Potarzycki, J. Phosphorus in soil. J. Elem. 2003, 8, 19-32.

58. Kennelly, P.J. Protein phosphatases-a phylogenetic perspective. Chem. Rev. 2001, 101, 2291-2312. [CrossRef]

59. Quiquampoix, H.; Mousain, D. Enzymatic hydrolysis of organic phosphorus. In Organic Phosphorus in the Environment; Turner, B.L., Frossard, E., Baldwin, D.S., Eds.; CABI Pub: Wallingford, UK; Cambridge, MA, USA, 2005; pp. 89-112.

60. Martínez-Espinosa, R.M.; Cole, J.A.; Richardson, D.J.; Watmough, N.J. Enzymology and ecology of the nitrogen cycle. Biochem. Soc. Trans. 2011, 39, 175-178. [CrossRef]

61. Nannipieri, P.; Giagnoni, L.; Landi, L.; Renella, G. Role of phosphatase enzymes in soil. In Phosphorus in Action; Bünemann, E., Oberson, A., Frossard, E., Eds.; Soil Biology; Springer: Berlin/Heidelberg, Germany, 2011; Volume 26, pp. 215-243.

62. Eivazi, F.; Tabatabai, M.A. Phosphatases in soils. Soil Biol. Biochem. 1977, 9, 167-172. [CrossRef]

63. Bielińska, E. Methods of determination of photosphatase activity. Acta Agroph. 2005, 3, 63-74.

64. Richardson, A.E.; Simpson, R.J. Soil microorganisms mediating phosphorus availability update on microbial phosphorus. Plant Physiol. 2011, 156, 989-996. [CrossRef]

65. Harasim, A. Straw Management; Publisher IUNG-PIB: Puławy, Poland, 2011; p. 77.

66. Smernik, R.J.; Baldock, J.A. Solid-state 15N NMR analysis of highly 15N-enriched plant materials. Plant Soil 2005, 275, 271-283. [CrossRef]

67. Zhao, F.J.; McGrath, S.P.; Blake-Kalff, M.M.A.; Link, A.; Tucker, M. Crop Responses to Sulphur Fertilisation in Europe; The International Fertiliser Society: York, UK, 2002; pp. 1-28.

68. Niknahad-Gharmakher, H.; Piutti, S.; Machet, J.-M.; Benizri, E.; Recous, S. Mineralization-immobilization of sulphur in a soil during decomposition of plant residues of varied chemical composition and $\mathrm{S}$ content. Plant Soil 2012, 360, 391-404. [CrossRef]

69. Eriksen, J. Gross sulphur mineralisation-immobilisation turnover in soil amended with plant residues. Soil Biol. Biochem. 2005, 37, 2216-2224. [CrossRef] 
70. Nicolardot, B.; Recous, S.; Mary, B. Simulation of C and N mineralisation during crop residue decomposition: A simple dynamic model based on the C:N ratio of the residues. Plant Soil 2001, 228, 83-103. [CrossRef]

71. Hadas, A.; Kautsky, L.; Goek, M.; Kara, E.E. Rates of decomposition of plant residues and available nitrogen in soil, related to residue composition through simulation of carbon and nitrogen turnover. Soil Biol. Biochem. 2004, 36, 255-266. [CrossRef]

72. Dannehl, T.; Leithold, G.; Brock, C. The effect of C:N ratios on the fate of carbon from straw and green manure in soil: The effect of C:N ratios on the fate of carbon from straw and green manure. Eur. J. Soil Sci. 2017, 68, 988-998. [CrossRef]

73. Hessen, D.O.; Ågren, G.I.; Anderson, T.R.; Elser, J.J.; De Ruiter, P.C. Carbon sequestration in ecosystems: The role of stoichiometry. Ecology 2004, 85, 1179-1192. [CrossRef]

74. Lynch, M.J.; Mulvaney, M.J.; Hodges, S.C.; Thompson, T.L.; Thomason, W.E. Decomposition, nitrogen and carbon mineralization from food and cover crop residues in the central plateau of Haiti. Springer Plus 2016, 5, 973. [CrossRef]

75. Thuriès, L. Biochemical composition and mineralization kinetics of organic inputs in a sandy soil. Soil Biol. Biochem. 2002, 34, 239-250. [CrossRef]

76. Magdoff, F.; Weil, R. Soil organic matter management strategies. In Soil Organic Matter in Sustainable Agriculture; Magdoff, F., Weil, R., Eds.; CRC Press: Boca Raton, FL, USA, 2004.

77. Machinet, G.E.; Bertrand, I.; Chabbert, B.; Recous, S. Decomposition in soil and chemical changes of maize roots with genetic variations affecting cell wall quality. Eur. J. Soil Sci. 2009, 60, 176-185. [CrossRef]

78. Sariyildiz, T.; Anderson, J.M. Decomposition of sun and shade leaves from three deciduous tree species, as affected by their chemical composition. Biol. Fertil. Soils 2003, 37, 137-146. [CrossRef]

79. Annoussamy, M.; Richard, G.; Recous, S.; Guérif, J. Change in mechanical properties of wheat straw due to decomposition and moisture. Appl. Eng. Agric. 2000, 16, 657-664. [CrossRef]

80. Magid, J.; Luxhøi, J.; Lyshede, O.B. Decomposition of plant residues at low temperatures separates turnover of nitrogen and energy rich tissue components in time. Plant Soil 2004, 258, 351-365. [CrossRef]

81. Abiven, S.; Recous, S.; Reyes, V.; Oliver, R. Mineralisation of C and N from root, stem and leaf residues in soil and role of their biochemical quality. Biol. Fertil. Soils 2005, 42, 119-128. [CrossRef]

82. Prieto, I.; Stokes, A.; Roumet, C. Root functional parameters predict fine root decomposability at the community level. J. Ecol. 2016, 104, 725-733. [CrossRef]

83. Zhang, X.; Wang, W. The decomposition of fine and coarse roots: Their global patterns and controlling factors. Sci. Rep. 2015, 5, 9940. [CrossRef] [PubMed]

84. Silver, W.L.; Miya, R.K. Global patterns in root decomposition: Comparisons of climate and litter quality effects. Oecologia 2001, 129, 407-419. [CrossRef]

85. Johnson, J.M.-F.; Barbour, N.W.; Weyers, S.L. Chemical composition of crop biomass impacts its decomposition. Soil Sci. Soc. Am. J. 2007, 71, 155-162. [CrossRef]

86. Kriaučiūnienè, Z.; Velička, R.; Raudonius, S. The influence of crop residues type on their decomposition rate in the soil: A litterbag study. Zemdirb. Agric. 2012, 99, 227-236.

87. Cabrera, M.L.; Kissel, D.E.; Vigil, M.F. Nitrogen mineralization from organic residues: Research opportunities. J Environ. Qual. 2005, 34, 75-79. [CrossRef]

88. Paśmionka, I. Microbiological transformations of soil nitrogen. Kosmos 2017, 66, 185-192.

89. Sapek, B.; Kalinowska, D. Mineralization of soil organic nitrogen compounds in the light of long-term grassland experiments in IMUZ. Water Environ. Rural Areas 2004, 4, 183-200.

90. Pangnakorn, U.; George, D.L.; Tullberg, J.N.; Gupta, M.L. Effect of tillage and traffic on earthworm populations in a vertosol in south-east Queensland. In Proceedings of the Soil Management for Sustainability, Brisbane, Australia, 13-18 July 2003; International Soil Tillage Research Organisation: Queensland, Australia, 2003.

91. Hu, R.; Wang, X.; Pan, Y.; Zhang, Y.; Zhang, H. The response mechanisms of soil N mineralization under biological soil crusts to temperature and moisture in temperate desert regions. Eur. J. Soil Biol. 2014, 62, 66-73. [CrossRef]

92. Chow, A.T.; Tanji, K.K.; Gao, S.; Dahlgren, R.A. Temperature, water content and wet-dry cycle effects on DOC production and carbon mineralization in agricultural peat soils. Soil Biol. Biochem. 2006, 38, 477-488. [CrossRef]

93. Paul, E.A. Soil Microbiology, Ecology and Biochemistry, 4th ed.; Academic Press: Waltham, MA, USA, 2014. 
94. Paul, K.I.; Polglase, P.J.; O'Connell, A.M.; Carlyle, J.C.; Smethurst, P.J.; Khanna, P.K. Defining the relation between soil water content and net nitrogen mineralization. Eur. J. Soil Sci. 2003, 54, 39-48. [CrossRef]

95. Devêvre, O.C.; Horwáth, W.R. Decomposition of rice straw and microbial carbon use efficiency under different soil temperatures and moistures. Soil Biol. Biochem. 2000, 32, 1773-1785. [CrossRef]

96. Kruse, J.S.; Kissel, D.E.; Cabrera, M.L. Effects of drying and rewetting on carbon and nitrogen mineralization in soils and incorporated residues. Nutr. Cycl. Agroecosyst. 2004, 69, 247-256. [CrossRef]

97. Fierer, N.; Schimel, J.P. Effects of drying-rewetting frequency on soil carbon and nitrogen transformations. Soil Biol. Biochem. 2002, 34, 777-787. [CrossRef]

98. Klocke, N.L.; Currie, R.S.; Aiken, R.M. Soil water evaporation and crop residues. Trans. ASABE 2009, 52, 103-110. [CrossRef]

99. Garbeva, P.; van Veen, J.A.; van Elsas, J.D. Microbial diversity in soil: Selection of microbial populations by plant and soil type and implications for disease suppressiveness. Annu. Rev. Phytopathol. 2004, 42, 243-270. [CrossRef]

100. Frøseth, R.B.; Bleken, M.A. Effect of low temperature and soil type on the decomposition rate of soil organic carbon and clover leaves, and related priming effect. Soil Biol. Biochem. 2015, 80, 156-166. [CrossRef]

101. Schmatz, R.; Recous, S.; Aita, C.; Tahir, M.M.; Schu, A.L.; Chaves, B.; Giacomini, S.J. Crop residue quality and soil type influence the priming effect but not the fate of crop residue C. Plant Soil 2017, 414, 229-245. [CrossRef]

102. Ekenler, M.; Tabatabai, M.A. Effects of trace elements on b-glucosaminidase activity in soils. Soil Biol. 2002, 34, 1829-1832. [CrossRef]

103. Kemmitt, S.; Wright, D.; Goulding, K.; Jones, D. pH regulation of carbon and nitrogen dynamics in two agricultural soils. Soil Biol. Biochem. 2006, 38, 898-911. [CrossRef]

104. Aciego Pietri, J.C.; Brookes, P.C. Nitrogen mineralisation along a pH gradient of a silty loam UK soil. Soil Biol. Biochem. 2008, 40, 797-802. [CrossRef]

105. Mandal, K.G.; Misra, A.K.; Hati, K.M.; Bandyopadhyay, K.K.; Ghosh, P.K.; Mohanty, M. Rice residuemanagement options and effects on soil properties and crop productivity. J. Food Agric. Environ. 2004, 2, 224-231.

106. Kumar, K.; Goh, K.M. Nitrogen Release from crop residues and organic amendments as affected by biochemical composition. Commun. Soil Sci. Plant Anal. 2003, 34, 2441-2460. [CrossRef]

107. Bergman, I.; Lundberg, P.; Nilsson, M. Microbial carbon mineralisation in an acid surface peat: Effects of environmental factors in laboratory incubations. Soil Biol. Biochem. 1999, 31, 1867-1877. [CrossRef]

108. Zhao, W.; Zhang, J.; Müller, C.; Cai, Z. Effects of $\mathrm{pH}$ and mineralisation on nitrification in a subtropical acid forest soil. Soil Res. 2018, 56, 275-283. [CrossRef]

109. Hu, H.-W.; Xu, Z.-H.; He, J.-Z. Chapter Six-Ammonia-oxidizing archaea play a predominant role in acid soil nitrification. In Advances in Agronomy; Sparks, D.L., Ed.; Academic Press: Cambridge, MA, USA, 2014; Volume 125, pp. 261-302.

110. Booth, M.S.; Stark, J.M.; Rastetter, E. Controls on nitrogen cycling in terrestrial ecosystems: A synthetic analysis of literature data. Ecol. Monogr. 2005, 75, 139-157. [CrossRef]

111. Bailey, K.L.; Lazarovits, G. Suppressing soil-borne diseases with residue management and organic amendments. Soil Tillage Res. 2003, 72, 169-180. [CrossRef]

112. Brankatschk, G.; Finkbeiner, M. Crop rotations and crop residues are relevant parameters for agricultural carbon footprints. Agron. Sustain. Dev. 2017, 37, 58. [CrossRef]

113. Pandiaraj, T.; Selvaraj, S.; Ramu, N. Effects of crop residue management and nitrogen fertilizer on soil nitrogen and carbon content and productivity of wheat (Triticum aestivum 1.) in two cropping systems. J. Agric. Sci. Technol. 2015, 17, 249-260.

114. Surekha, K.; Kumari, A.P.P.; Reddy, M.N.; Satyanarayana, K.; Cruz, S. Crop residue management to sustain soil fertility and irrigated rice yields. Nutr. Cycl. Agroecosyst. 2003, 67, 145-154. [CrossRef]

115. Shafi, M.; Bakht, J.; Khan, M.A. Effects of crop sequence and crop residues on soil C, soil N and yield of maize. Pak. J. Bot. 2010, 42, 1651-1664.

116. Arnault, I.; Fleurance, C.; Vey, F.; Fretay, G.D.; Auger, J. Use of Alliaceae residues to control soil-borne pathogens. Ind. Crops Prod. 2013, 49, 265-272. [CrossRef] 
117. Arnault, I.; Huchette, O.; Auger, J. Characterisation of Aroma "Type" in Allium species according to their s-alk(en)yl cysteine sulfoxides and $\gamma$-glutamyl dipeptides contents. In Proceedings of the International Symposium on Medicinal and Aromatic Plants, Djerba, Tunisia, 26-28 March 2009; ISHS, International Society for Horticultural Science: Hague, The Natherlands, 2010; pp. 171-182.

118. Wang, D.; Rosen, C.; Kinkel, L.; Cao, A.; Tharayil, N.; Gerik, J. Production of methyl sulfide and dimethyl disulfide from soil-incorporated plant materials and implications for controlling soilborne pathogens. Plant Soil 2009, 324, 185-197. [CrossRef]

119. Kerdraon, L.; Laval, V.; Suffert, F. Microbiomes and pathogen survival in crop residues, an ecotone between plant and soil. Phytobiomes J. 2019, 3, 246-255. [CrossRef]

120. Suffert, F.; Sache, I. Relative importance of different types of inoculum to the establishment of Mycosphaerella graminicola in wheat crops in north-west Europe. Plant Pathol. 2011, 60, 878-889. [CrossRef]

121. Vera, D.I.; Murray, T.D. Occurrence and survival of spothecia of the syespot pathogens oculimacula acuformis and O. yallundae on wheat stubble in the U.S. Pacific Northwest. Plant Dis. 2016, 100, 991-995. [CrossRef]

122. Jones, E.; Jessop, R.S.; Sindel, B.M.; Hoult, A. Utilising crop residues to control weeds. In Proceedings of the 12th Australian Weeds Conference, Papers and Proceedings, Weed Management into the 21st Century: Do We Know Where We're Going? Hobart, Tasmania, Australia, 12-16 September 1999; University of Tasmania: Hobart, Australia, 1999.

123. Chauhan, B.S.; Singh, R.G.; Mahajan, G. Ecology and management of weeds under conservation agriculture: A review. Crop Prot. 2012, 38, 57-65. [CrossRef]

124. Directive 2009/128/EC of the European Parliament and of the Council of 21 October 2009 Establishing a Framework for Community Action to Achieve the Sustainable Use of Pesticides, Text with EEA Relevance. Official Journal of the European Union, 2009. Available online: https://eur-lex.europa.eu/legal-content/EN/ALL/ ?uri=celex\%3A32009L0128 (accessed on 1 September 2020).

125. Regulation (EC) No 1107/2009 of the European Parliament and of the Council of 21 October 2009 Concerning the Placing of Plant Protection Products on the Market and Repealing Council Directives 79/117/EEC and 91/414/EEC. Official Journal of the European Union, 2009. Available online: https://eur-lex.europa.eu/legalcontent/EN/TXT/?uri=celex\%3A32009R1107 (accessed on 1 September 2020).

Publisher's Note: MDPI stays neutral with regard to jurisdictional claims in published maps and institutional affiliations.

(C) 2020 by the authors. Licensee MDPI, Basel, Switzerland. This article is an open access article distributed under the terms and conditions of the Creative Commons Attribution (CC BY) license (http://creativecommons.org/licenses/by/4.0/). 